Article

\title{
Packaging as an Offline Method to Share Information: Evidence from the Food and Beverage Industry in the Republic of Korea
}

\author{
Bulim Choi ${ }^{1}$ and Kang-Dae Lee ${ }^{2, *}$ \\ 1 Logistics System Research Team, Korea Railroad Research Institute, Uiwang 16105, Korea; \\ greatchoi@krri.re.kr \\ 2 Department of Packaging, Yonsei University, Wonju 26493, Korea \\ * Correspondence: pimeson@yonsei.ac.kr; Tel.: +82-33-760-2241
}

Received: 19 August 2019; Accepted: 31 October 2019; Published: 11 November 2019

\begin{abstract}
With the growing participation by diverse stakeholders in the total flow of products, as seen with supply chains and logistics, it is becoming increasingly complicated to decide what information is to be shared and who is to be a partner. The purpose of this study is to explore the role of packaging as an offline method to share information in the total channel. This is because packaging improves communication among stakeholders and is normally part of the first contact between them and the product. Thus, it has the strategic potential to share product information that meets stakeholders' needs. To accomplish this objective, we built a research framework that depicts four hypotheses and tested it with structural equation modeling (SEM). Data were collected by surveys and measured for statistical analysis. After identifying the role of packaging, we showed nine specific related variables and the information's perceived effects on stakeholders and their directions and relative values. This will help future researchers to discuss packaging's extended roles, the needs of information separation, and its priority to be shared to help executives develop packaging strategies as an offline means to share information. Additionally, as packaging is considered to be an information generator, it gives participants the opportunity to extend its roles and to assign additional information to the product along the offline flow of goods from manufacturers to end users.
\end{abstract}

Keywords: packaging; logistics; information sharing; structural equation

\section{Introduction}

Information sharing is a strategy to integrate stakeholders in the total channel, including supply chains and logistics [1]. It is essential for sharing useful and effective information with partners [2]. With the growth in participation by diverse stakeholders, it is becoming more complicated to determine which information is to be shared and who to include as a partner [3]. However, both costs and risks stemming from increasing complexity are limitations of information-sharing strategies [4], and stakeholders' profits are occasionally not practical or fall short of their expectations $[5,6]$. Packaging is, meanwhile, an essential strategy [7], and its positive impacts are comprehensively provided through logistic processes in supply chains [8-11] and on the efficiency of manufacturing, distribution, and goods handling [12]. By contrast, offline communication is achieved with packaging, which improves communication among stakeholders $[13,14]$ because it is normally part of the first contact between them and the product.

The purpose of this study is to explore the role of packaging as an offline method to share information in the total channel. To accomplish this objective, it is necessary to separate packaging from manufacturing and treat it as a generator of product information. For example, the handling of goods 
is product information, which is sharing within stakeholders rather than manufacturing information. This distinction in information enables diverse stakeholders to assign additional information to packaging along the offline flow of goods, ranging from manufacturers to end users. This helps us to answer the research questions: What is packaging's role in the sharing of information? What information is necessary? Who shares it with whom? And to what extent is shared information helpful and effective?

This research was comprised of four sections. For the first section, we built a research framework that depicts our hypotheses. For the second section, data were collected by surveys and measured for statistical analysis. For the third section, we tested the research framework with structural equation modeling (SEM) and described our results. In the last section, we conclude and discuss our findings, their implications, and the study's limitations and recommend further research.

\section{Literature Review and Hypotheses Development}

Information sharing produces more profit for stakeholders [15] and increases the cooperativity of their relationships [16]. Sharable information includes necessities such as tactical, strategic, and decisive information [17]; confidential ideas, plans, and processes [18]; and general data and knowledge [19-21]. Delivery information helps manufacturers reduce overages [22] and includes product quantities, delivery type, routes, shipment rates, transportation equipment-use plans, traceability, and loading capacity [23]. Sharing of scheduling and routing improves the efficiency of delivery, rapidly meeting customers' needs [24,25]. This sharing is more profitable to customers than to raw material suppliers $[26,27]$ and improves delivery performance with positive communication among stakeholders [28]. Traceability is particularly essential information to be shared [29]. Manufacturing information affects forwarding agents who generate the delivery information's effect on customers and covers production planning, lead time, orders, demand data/forecasts, and procurement [30,31], as well as sales volume, inspection date, price, status, delay [32,33], daily orders [34], and made-to-order items [35]. Order sharing strengthens stakeholders' relations [36], demand forecast sharing produces practical benefits $[37,38]$, and lead time sharing helps supply chain management to be more effective [39,40]. It is not profitable, however, to share lead time without customers' needs [41]. The sharing of manufacturing information is explored with sales and operations planning [42] and with a resource-based view [43]. Based on these considerations, we formulated the following hypotheses:

H1: Delivery information has positive effects on customers who produce customer information.

\section{H2: Manufacturing information has positive effects on forwarding agents who produce delivery information.}

Packaging design is represented by an integrated management model [44], and logistics-driven packaging is identified and its strategic potential described [45] and explored for supply chain needs [46]. This makes for efficient transportation [47] and a sustainable supply chain regarding transformation aspects [48]. Its system is examined for logistical and environmental performance [49], and returnable packaging is helpful for reverse resource exchanges [50-52]. Information is shared online using information and communication technologies (ICT) [53-56]. As for manufacturers, both manufacturing and product information are produced independently. However, the two types of information play different roles within total channels. Packaging is not affected by manufacturing but, rather, they are separate from each other. Therefore, well-defined packaging information is critical to meet stakeholders' expectations and achieve efficient supply chains [57]. Its extent is examined in the secondary packaging [58] and affects consumer perceptions of labels and brand names [59-61]. The use of a food consumption database is collected differently by the contact consumer [62]. There is a difference between how males and females perceive information from healthy food packaging [63]. The choice of cosmetic creams, although they are not a food or beverage, is influenced by product composition, product information, and brand image [64]. Both the customers' demographic changes and the growth in demand for healthy food have resulted in smaller packs, information about product origin, and quality/ecofriendly certification for personal needs, influencing manufacturer behaviors. 
This trend illustrates the indispensable role of packaging [65] and its promotion of competitiveness [66]. Including product information on packaging communicates that information to customers [67], shares it with other stakeholders, and helps companies' logistical and supply chain needs by using ICT [68-70]. Based on these considerations, we formulated the following hypotheses:

H3: Manufacturing information has positive effects on packaging that produces product information.

H4: Customer information has positive effects on packaging that produces product information.

The research framework was set up with the above hypotheses, which are based on results of the previous literatures, as shown in Figure 1.

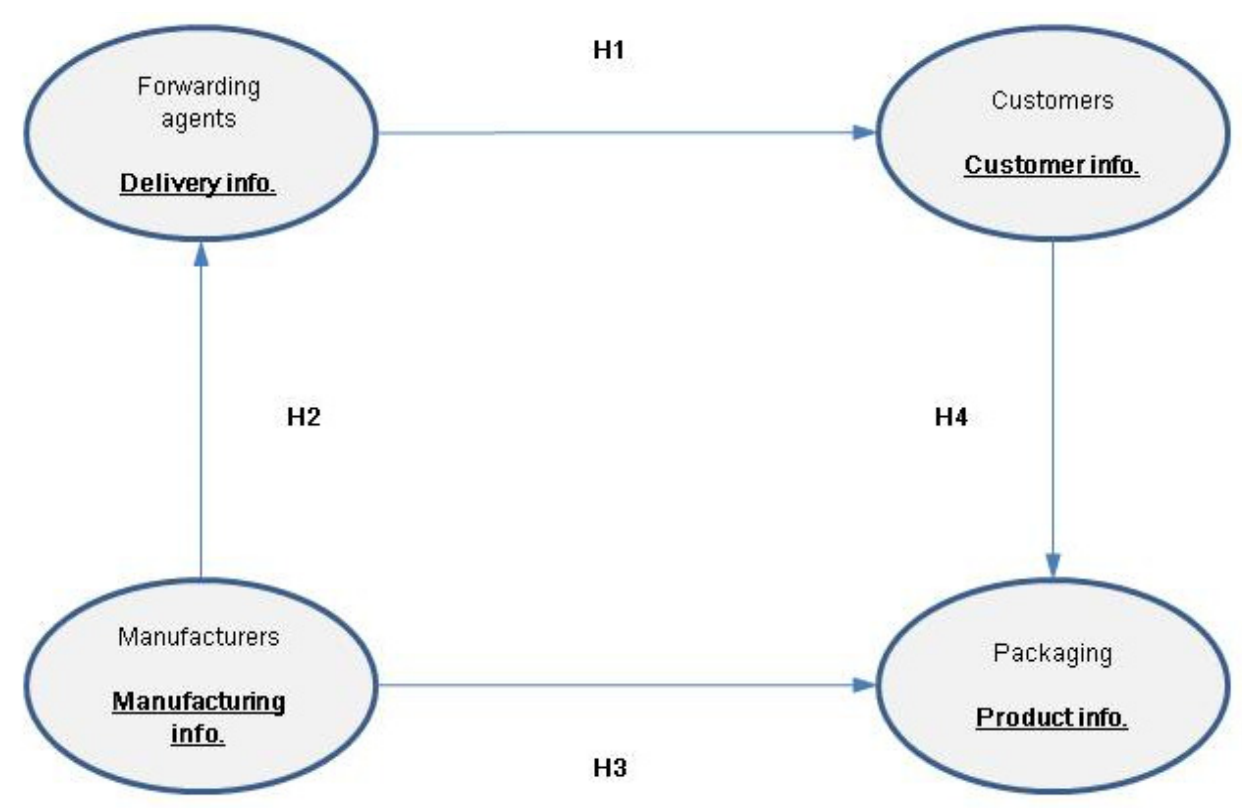

Figure 1. Research framework for H1 (hypothesis 1), H2 (hypothesis 2), H3 (hypothesis 3), and H4 (hypothesis 4).

\section{Research Methodology}

\subsection{Operational Definition of Variables}

All 25 variables were divided into four latent types: manufacturing information, delivery information, customer information, and product information. The 25 observed variables were generated from manufacturers, forwarding agents, customers, and packaging. Operational definitions of all variables are shown in Table 1.

Table 1. Definitions of variables.

\begin{tabular}{ccc}
\hline Latent Variables & Observed Variables & Definition \\
\hline \multirow{3}{*}{ Manufacturing information } & Ma1 & Production planning \\
& Ma2 & Lead time \\
& Ma3 & Order processing \\
& Ma5 & Rate of production \\
Ma6 & Defective products \\
Delivery information & Pe2 & Production cost \\
& De3 & Consolidation service \\
& De4 & Delivery scheduling \\
& De5 & Delivery type \\
& & Transport path \\
\end{tabular}


Table 1. Cont.

\begin{tabular}{ccc}
\hline Latent Variables & Observed Variables & Definition \\
\hline \multirow{3}{*}{ Customer information } & $\mathrm{Cu} 1$ & Age \\
& $\mathrm{Cu} 2$ & Gender \\
& $\mathrm{Cu} 3$ & Residence \\
& $\mathrm{Cu} 4$ & Average income \\
& $\mathrm{Cu} 5$ & Consumption patterns \\
& $\operatorname{Pr} 1$ & Origin \\
Product information & $\operatorname{Pr} 2$ & Packaging material \\
& $\operatorname{Pr} 3$ & Manufacturer \\
& $\operatorname{Pr} 4$ & Security indication \\
& $\operatorname{Pr} 5$ & Quality certification \\
& $\operatorname{Pr} 6$ & Handling of goods \\
& $\operatorname{Pr} 7$ & Ecofriendly certification \\
& $\operatorname{Pr} 8$ & Packing unit/size \\
& $\operatorname{Pr} 9$ & Labeling and advertising \\
\hline
\end{tabular}

\subsection{Sampling and Data Collection}

To conduct this research, we designed a questionnaire (see Appendix A). Respondents were categorized into manufacturers, forwarding agents, customers, and packagers, each of which has a different role in producing information. Packagers' tasks are particularly separate from those of manufacturers because manufacturers are involved in generating information from Ma1 (production planning) to Ma6 (production cost), whereas packagers are involved from $\operatorname{Pr} 1$ (origin) to $\operatorname{Pr} 9$ (labeling and advertising). Characteristics of the respondents are shown in Table 2. We informed the questionnaire respondents of the objective of our survey on the first page. They were asked to rank the 25 variables, from De1 (consolidation service) to Cu5 (consumption patterns), on a five-point Likert-type scale ranging from $1=$ "of no importance" to $5=$ "of major importance." The response rate was $21.4 \%$ (240/1121).

Table 2. Respondents' characteristics.

\begin{tabular}{cccccc}
\hline Category & \multicolumn{2}{c}{ Data } & Service Years & \multicolumn{2}{c}{ Data } \\
\hline Customer & 60 & $25.0 \%$ & More than 15 & 96 & $40.0 \%$ \\
Manufacturer & 68 & $28.3 \%$ & 10 to 14 & 116 & $48.3 \%$ \\
Forwarding agent & 58 & $24.2 \%$ & 5 to 9 & 28 & $11.7 \%$ \\
Packager & 54 & $22.5 \%$ & 0 to 4 & 0 & $0 \%$ \\
\hline
\end{tabular}

\subsection{Hoelter's Critical N}

Hoelter's critical $\mathrm{N}$ index focuses on the adequacy of the sample size rather than the model fit $[71,72]$. An adequate sample size is shown in Table 3. A Hoelter 0.05 value indicates that a sample size exceeding 88 is adequate, and a Hoelter 0.01 value indicates that a sample size exceeding 104 is adequate. The sample size of 240 is adequate for this research.

Table 3. Hoelter's Critical N.

\begin{tabular}{ccc}
\hline Model & HOELTER 0.05 & HOELTER 0.01 \\
\hline Default model & 88 & 104 \\
Independence model & 15 & 18 \\
\hline
\end{tabular}

\subsection{Measurement of Variables}

Kurtosis is more reasonable than skewness in assessing the normality of data [73]. The normality of observed variables will be rejected when each critical ratio (CR) is greater than |1.645|, the test statistic of 
the one-tailed side test $(\alpha=0.05)$ [74]. Non-normal distributed variables are Ma3 (order processing), Ma4 (rate of production), Ma5 (defective products), Ma6 (production cost), De2 (delivery scheduling), De3 (delivery type), De4 (transport path), Cu3 (residence), Cu4 (average income), Cu5 (consumption patterns), Pr1 (origin), Pr2 (packaging material), Pr3 (manufacturer), Pr4 (security indication), Pr8 (packing unit/size), and Pr9 (labeling and advertising). These variables cannot be used because each critical ratio of these observed variables is greater than $|1.645|$ at $\alpha=0.05$. Therefore, nine variables that have normality were used for the research (Ma1, Ma2 (lead time), De1, De5 (traceability and confirmation of delivery), Cu1 (age), Cu2 (gender), Pr5 (quality certification), Pr6 (handling of goods), and Pr7(ecofriendly certification)). Multivariate normality is accepted with a multivariate kurtosis of 1.439 and $\alpha=0.01$. The assessment of normality is shown in Table 4 .

Table 4. Assessment of normality.

\begin{tabular}{ccccccc}
\hline Variable & Min & Max & Skew & Critical Ratio (CR) & Kurtosis & Critical Ratio (CR) \\
\hline Ma1 & 1.000 & 5.000 & -0.630 & -3.986 & -0.097 & -0.308 \\
Ma2 & 1.000 & 5.000 & -0.528 & -3.340 & -0.275 & -0.869 \\
Ma3 & 2.000 & 5.000 & -0.112 & -0.711 & -0.690 & -2.181 \\
Ma4 & 1.000 & 5.000 & -0.869 & -5.496 & 0.770 & 2.436 \\
Ma5 & 1.000 & 5.000 & -0.220 & -1.391 & -0.703 & -2.224 \\
Ma6 & 1.000 & 5.000 & 0.397 & 2.508 & -0.677 & -2.139 \\
De1 & 1.000 & 5.000 & -0.547 & -3.457 & 0.300 & 0.949 \\
De2 & 3.000 & 5.000 & -0.459 & -2.903 & -0.715 & -2.260 \\
De3 & 1.000 & 5.000 & -0.377 & -2.382 & -0.583 & -1.843 \\
De4 & 1.000 & 5.000 & -0.651 & -4.118 & -0.586 & -1.852 \\
De5 & 1.000 & 5.000 & 0.492 & 3.110 & -0.463 & -1.463 \\
Cu1 & 2.000 & 5.000 & -0.565 & -3.575 & -0.254 & -0.802 \\
Cu2 & 2.000 & 5.000 & -0.739 & -4.673 & -0.104 & -0.329 \\
Cu3 & 1.000 & 5.000 & -0.529 & -3.346 & -0.661 & -2.091 \\
Cu4 & 1.000 & 5.000 & -0.487 & -3.080 & -0.689 & -2.179 \\
Cu5 & 1.000 & 5.000 & -0.934 & -5.907 & 0.676 & 2.138 \\
Pr1 & 2.000 & 5.000 & -0.081 & -0.513 & -0.687 & -2.171 \\
Pr2 & 2.000 & 5.000 & 0.086 & 0.545 & -0.965 & -3.053 \\
Pr3 & 2.000 & 5.000 & -0.431 & -2.728 & -0.713 & -2.255 \\
Pr4 & 2.000 & 5.000 & -0.292 & -1.847 & -0.880 & -2.781 \\
Pr5 & 2.000 & 5.000 & -0.614 & -3.882 & -0.050 & -0.159 \\
Pr6 & 1.000 & 5.000 & -0.593 & -3.752 & -0.408 & -1.291 \\
Pr7 & 2.000 & 5.000 & -0.435 & -2.754 & -0.092 & -0.292 \\
Pr8 & 1.000 & 5.000 & -0.400 & -2.527 & -0.937 & -2.963 \\
Pr9 & 2.000 & 5.000 & 0.051 & 0.321 & -0.849 & -2.683 \\
Multivariate & & & & & 6.827 & 1.439 \\
\hline & & & & & &
\end{tabular}

\section{Results}

\subsection{Reliability and Validity}

Each Cronbach's alpha of the variables is greater than 0.7 , and each average variance extracted (AVE) is greater than 0.5 , as shown in Table 5. Both reliability and validity are confirmed with the results. Nine observed variables were selected to explain the four latent variables of manufacturing information, delivery information, customer information, and product information. Regression weights were used: Ma1 was weighted by 0.1, De1 was weighted by 1.0, Cu1 was weighted by 0.2, and Pr6 was weighted by 0.7 .

Manufacturing information is mostly explained by Ma1 (production planning) and Ma2 (lead time) of six observed variables. Delivery information is mostly explained by De1 (consolidation service) and De5 (traceability and confirmation of delivery) from five observed variables. Customer information is mostly explained by Cu1 (age) and Cu2 (gender) from five observed variables. Product information 
is mostly explained by $\operatorname{Pr} 5$ (quality certification), Pr6 (handling of goods), and Pr7 (ecofriendly certification) from nine observed variables.

Table 5. AVE and Cronbach's alpha.

\begin{tabular}{|c|c|c|c|c|c|c|c|c|}
\hline Latent Variable & $\begin{array}{l}\text { Observed } \\
\text { Var. }\end{array}$ & $\begin{array}{l}\text { Non-std. } \\
\text { Estimate }\end{array}$ & $\begin{array}{c}\text { Std. } \\
\text { Estimate }\end{array}$ & $\begin{array}{l}\text { Std. } \\
\text { Error }\end{array}$ & $\begin{array}{l}\text { Variance } \\
\text { Error }\end{array}$ & $\begin{array}{l}\text { Composite } \\
\text { Reliability }\end{array}$ & $\begin{array}{l}\text { Average } \\
\text { Variance } \\
\text { Extracted }\end{array}$ & $\begin{array}{c}\text { Critical } \\
\text { Ratio }\end{array}$ \\
\hline \multirow{2}{*}{ Manufacturing information } & Ma1 & 0.100 & 0.404 & - & 0.972 & - & \multirow{2}{*}{0.850} & \multirow{2}{*}{0.718} \\
\hline & Ma2 & 0.309 & 1.240 & 0.141 & $(0.633)$ & 2.196 & & \\
\hline \multirow{2}{*}{ Delivery information } & De1 & 0.480 & 0.589 & 0.106 & 0.483 & 4.508 & \multirow{2}{*}{0.582} & \multirow{2}{*}{0.700} \\
\hline & De5 & 1.000 & 0.904 & - & 0.250 & - & & \\
\hline \multirow{3}{*}{ Product information } & $\operatorname{Pr} 5$ & 0.561 & 0.692 & 0.065 & 0.344 & 8.568 & \multirow{3}{*}{0.556} & \multirow{3}{*}{0.793} \\
\hline & Pr6 & 0.700 & 0.599 & - & 0.833 & - & & \\
\hline & Pr7 & 0.715 & 0.912 & 0.105 & 0.104 & 6.783 & & \\
\hline
\end{tabular}

\subsection{Correlations}

The latent variables have no correlations with each other. The result of correlation analysis is shown in Table 6.

Table 6. Results of correlation analysis.

\begin{tabular}{ccccc}
\hline & $\begin{array}{c}\text { Manufacturing } \\
\text { Information }\end{array}$ & $\begin{array}{c}\text { Delivery } \\
\text { Information }\end{array}$ & $\begin{array}{c}\text { Customer } \\
\text { Information }\end{array}$ & $\begin{array}{c}\text { Product } \\
\text { Information }\end{array}$ \\
\hline Manufacturing information & 1.000 & - & - & - \\
Delivery information & 0.196 & 1.000 & - & - \\
Customer information & 0.075 & 0.381 & 1.000 & - \\
Product information & 0.277 & 0.211 & 0.446 & 1.000 \\
\hline
\end{tabular}

\subsection{Hypothesis Test}

Delivery information from forwarding agents is helpful to customers [23,29]. Manufacturing information is helpful to forwarding agents $[7,30,31,33]$ and is effective for packaging agents $[9,13,14]$. Packaging is positively affected by customer information such as age and gender $[57,65]$. Each hypothesis is accepted based on the results of the hypothesis test, as shown in Table 7.

Table 7. Results of hypothesis test $(\alpha=0.01)$.

\begin{tabular}{|c|c|c|c|c|c|c|}
\hline & Hypothesis & Estimate & $\begin{array}{c}\text { Std. } \\
\text { Estimate }\end{array}$ & Std. Error & $\begin{array}{l}\text { Composite } \\
\text { Reliability }\end{array}$ & \\
\hline H1 & Customer $\leftarrow$ Delivery information & 1.422 & 0.381 & 0.365 & 3.894 & Accepted \\
\hline $\mathrm{H} 2$ & Forwarding agent $\leftarrow$ Manufacturing information & 0.048 & 0.196 & 0.014 & 3.290 & Accepted \\
\hline H3 & Packaging $\leftarrow$ Manufacturing information & 0.056 & 0.245 & 0.015 & 3.726 & Accepted \\
\hline $\mathrm{H} 4$ & Packaging $\leftarrow$ Customer information & 0.109 & 0.428 & 0.020 & 5.376 & Accepted \\
\hline
\end{tabular}

The fit indices were chosen using three principles [75-80]. First, the index cannot be easily changed by sample size. Second, the index can indicate the model parsimony. Third, the index cannot be easily changed with many kinds of estimations. The recommended indices depending on these principles are shown in Table 8. These indices fit the recommended threshold values. Hence, the model is acceptable. Although these indices are acceptable, the reliability and validity of the model have to be preferentially verified, as shown in Table 5.

Table 8. Results of goodness of fit.

\begin{tabular}{cccccccccc}
\hline Model & RMR & GFI & IFI & CFI & RMSEA & CMIN & DF & P & CMIN/DF \\
\hline Default model & 0.053 & 0.922 & 0.908 & 0.907 & 0.115 & 96.281 & 23 & 0.000 & 4.186 \\
\hline
\end{tabular}




\subsection{Effects of Relationships}

Standardized coefficients have the same correlations (value 1.0) in structural equation modeling. There is no effect when a coefficient is 0.0 and there is a strong effect on the causal relationship with a high coefficient. The standardized coefficient is used to examine its relative weight among variables. Total effects are shown in Figure 2 and Table 9.

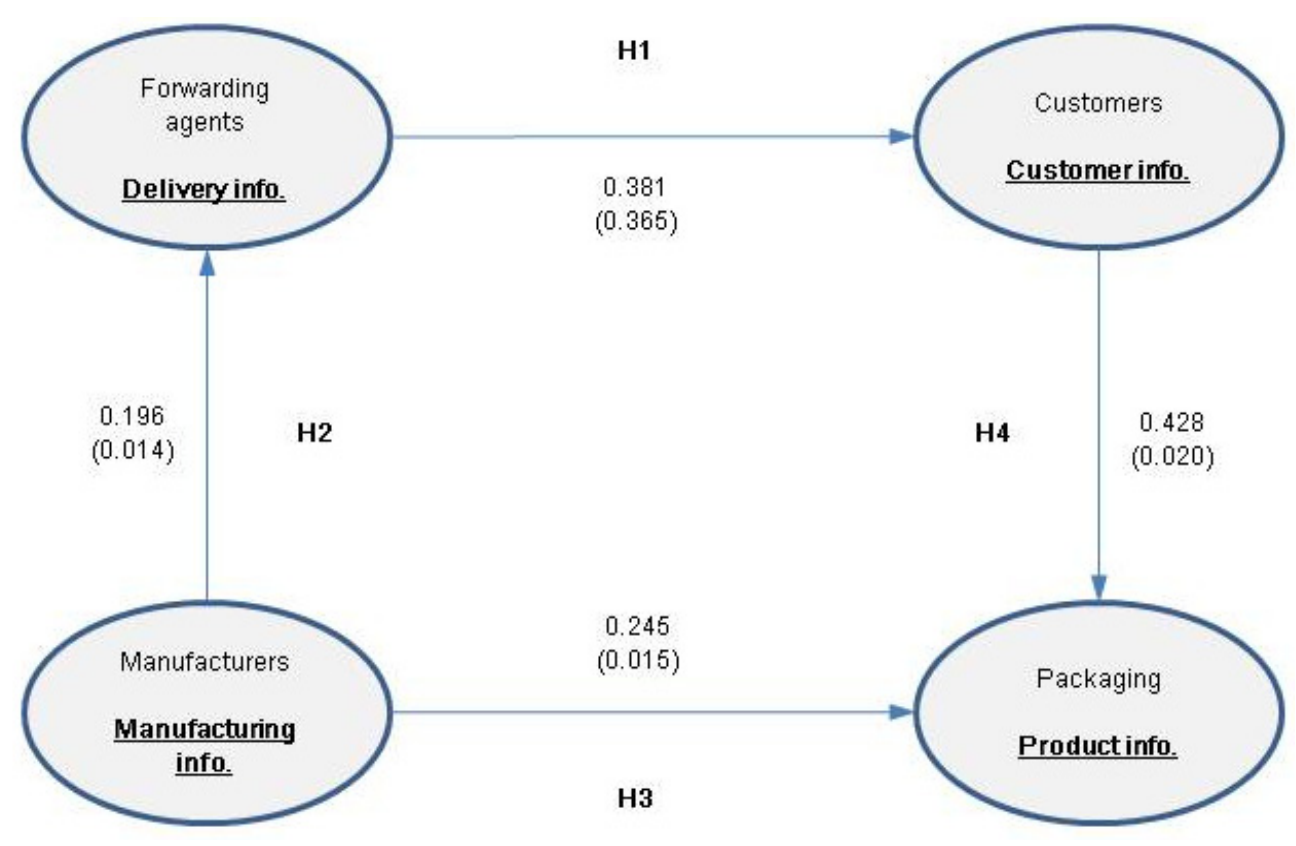

Figure 2. Results of structural equation modeling.

Table 9. Total effects.

\begin{tabular}{ccccc}
\hline Independent Variables & Dependent Variables & Direct Effect & Indirect Effect & Total Effect \\
\hline \multirow{2}{*}{ Delivery } & Manufacturer & 0.196 & 0.000 & 0.196 \\
& Customer & 0.000 & 0.000 & 0.000 \\
& Product & 0.000 & 0.000 & 0.000 \\
Customer & Manufacturer & 0.000 & 0.075 & 0.075 \\
& Delivery & 0.381 & 0.000 & 0.381 \\
& Product & 0.000 & 0.000 & 0.000 \\
Product & Manufacturer & 0.245 & 0.032 & 0.277 \\
& Delivery & 0.000 & 0.163 & 0.163 \\
& Customer & 0.428 & 0.000 & 0.428 \\
\hline
\end{tabular}

Delivery information has a direct effect (0.196) on manufacturers and no indirect effect $(0.000)$. Customer information has an indirect effect (0.075) on manufacturers and a direct effect (0.381) on forwarding agents. Product information has both a direct effect $(0.245)$ and an indirect effect (0.032) on manufacturers, and its total effect comes to 0.277 , as well as an indirect effect $(0.163)$ on forwarding agents and a direct effect $(0.428)$ on customers. Based on the results, delivery information is effective for manufacturers. This appears to be based on the fact that delivery information represents observed variables like consolidation service, traceability, and confirmation of delivery. Customer information is more effective on forwarding agents than on manufacturers, giving forwarding agents the insight to consider customer information (age and gender) in primary delivery service factors. Product information is more effective on customers than on forwarding agents. Even if it is limited to Pr5, Pr6, and Pr7, this result provides deeper insight into manufacturers than forwarding agents $[13,14]$ and customers $[57,67]$. This is because manufacturers play decisive roles in making product information, more strategic and more effective with by collaborating with packagers, including from $\operatorname{Pr} 1$ to $\operatorname{Pr} 9$. 


\section{Discussion and Conclusions}

This research aimed to explore the role of packaging as an offline method to share information within the total channel, including supply chains and logistics. The four-hypotheses research framework was tested with 240 sets of data collected from respondents in the food and beverage industry in the Republic of Korea.

\subsection{Findings and Implications}

Based on the observed role of packaging, we found nine specific variables and the information's perceived effects on stakeholders, their directions, and relative values. This helps future researchers discuss packaging's extended role, the need for information separation, its priority for sharing, and executives' development of a packaging strategy as an offline way to share information. Findings and implication are as follows.

What is packaging's role to share information? Packaging delivers product information and shares it with stakeholders in an offline total channel. When packaging is considered as a generator of product information, it gives diverse participants ways to extend its role and assign additional information. The distinction of information helps packaging play a role in assisting online information sharing as well as the offline flow of goods from manufacturers to end users. This improves stakeholders' competitive edge and answers the next questions directly or indirectly.

Which information is necessary? To answer this, we categorized information to be shared among stakeholders into four latent variables and explained them with 25 observed variables. Only nine observed variables were chosen and used to examine the research framework because the other 16 did not show normality. Manufacturing information was represented with production planning and lead time, delivery information with consolidation service and scheduling, customer information with age and gender, and product information with quality certification, handling of goods, and ecofriendly certification.

Who shares information with whom? To answer this, it was necessary to clarify the direction of the information flow within stakeholders. For this, we introduced packaging as an offline product information generator into the research framework. This allowed us to test relations between manufacturers and packaging, packaging and customers, and manufacturers and forwarding agents. Customer information is more effective for forwarding agents than for manufacturers, and delivery information from forwarding agents is helpful to manufacturers. This gives forwarding agents the insight to consider the customer as the primary service factor. Furthermore, packaging generates more effective information for customers than for forwarding agents. This gives a deeper insight into manufacturers rather than forwarding agents as they play decisive roles in making product information more strategic and more effective with the packers' collaboration.

Finally, to what extent is shared information helpful and effective? To answer this, the research framework was composed of four hypotheses to describe information effects on stakeholders and was tested using structural equation modeling. The effects are perceived by respondents and their values are relative. In terms of total effects, they are enumerated in rank: product information to customers (0.428), customer information to forwarding agents $(0.381)$, product information to manufacturers (0.277), delivery information to manufacturers (0.196), product information to forwarding agents (0.163), and customer information to manufacturers (0.75).

\subsection{Limitations and Further Research}

The 25 variables were described as sharable information and assessed for normality in statistical analysis. Nine variables were chosen as the other 16 did not show normality. It is conceivable that they might be chosen for further research and, accordingly, the factor score weights of the chosen variables were added, as listed in Appendix B. Standardized coefficients of effects were used to compare them with each other. The comparison of estimated effects could not help but be limited to the use 
of standardized coefficients and to the scope of the food and beverage industry in the Republic of Korea. Non-standard coefficients of effects are listed in Appendix C. This enables future researchers to compare these results with their own future results. Both the information priority and its relative effectiveness, with additional comments, could depend on industry scope, country, and relationship levels among stakeholders.

Author Contributions: Data curation, B.C.; Formal analysis, B.C.; Methodology, K.-D.L.; Project administration, B.C.; Supervision, K.-D.L.; Writing, B.C.; Review and editing, K.-D.L.

Funding: This research received no external funding.

Conflicts of Interest: The authors declare no conflicts of interest.

\section{Appendix A}

Table A1. Abridged Questionnaire.

\begin{tabular}{|c|c|c|c|c|c|c|c|}
\hline \multirow{2}{*}{$\begin{array}{l}\text { Information } \\
\text { (Latent) }\end{array}$} & \multirow{2}{*}{$\begin{array}{l}\text { Subinformation } \\
\text { (Observed) }\end{array}$} & \multirow{2}{*}{ Definition } & \multicolumn{5}{|c|}{ Importance } \\
\hline & & & 1 & 2 & 3 & 4 & 5 \\
\hline \multirow{5}{*}{$\begin{array}{c}\text { Delivery } \\
\text { information }\end{array}$} & De1 & Consolidation service & & & & & \\
\hline & De2 & Delivery scheduling & & & & & \\
\hline & De3 & Delivery type & & & & & \\
\hline & De4 & Transport path & & & & & \\
\hline & De5 & Traceability and confirmation of delivery & & & & & \\
\hline \multirow{6}{*}{$\begin{array}{l}\text { Manufacturing } \\
\text { information }\end{array}$} & Ma1 & Production planning & & & & & \\
\hline & Ma2 & Lead time & & & & & \\
\hline & Ma3 & Order processing & & & & & \\
\hline & Ma4 & Rate of production & & & & & \\
\hline & Ma5 & Defective products & & & & & \\
\hline & Ma6 & Production cost & & & & & \\
\hline \multirow{9}{*}{$\begin{array}{l}\text { Product } \\
\text { information }\end{array}$} & Pr1 & Origin & & & & & \\
\hline & $\operatorname{Pr} 2$ & Packaging material & & & & & \\
\hline & Pr3 & Manufacturer & & & & & \\
\hline & Pr4 & Security indication & & & & & \\
\hline & $\operatorname{Pr} 5$ & Quality certification & & & & & \\
\hline & Pr6 & Handling of goods & & & & & \\
\hline & Pr7 & Ecofriendly certification & & & & & \\
\hline & Pr8 & Packing unit/size & & & & & \\
\hline & $\operatorname{Pr} 9$ & Labeling and advertising & & & & & \\
\hline \multirow{5}{*}{$\begin{array}{l}\text { Customer } \\
\text { information }\end{array}$} & Cu1 & Age & & & & & \\
\hline & $\mathrm{Cu} 2$ & Gender & & & & & \\
\hline & $\mathrm{Cu} 3$ & Residence & & & & & \\
\hline & $\mathrm{Cu} 4$ & Average income & & & & & \\
\hline & Cu5 & Consumption patterns & & & & & \\
\hline
\end{tabular}

\section{Appendix B}

Table A2. Factor Score Weights.

\begin{tabular}{cccccccccc}
\hline & Ma1 & Ma2 & De1 & De5 & Cu1 & Cu2 & Pr5 & Pr6 & Pr7 \\
\hline Manufacturing & -1.245 & 5.909 & -0.094 & -0.378 & 0.168 & 0.139 & -0.190 & -0.092 & -0.799 \\
Delivery & -0.010 & 0.046 & 0.178 & 0.719 & 0.046 & 0.038 & -0.001 & 0.000 & -0.002 \\
Customer & 0.012 & -0.055 & 0.031 & 0.123 & 2.339 & 1.934 & 0.050 & 0.024 & 0.210 \\
Product & -0.012 & 0.057 & 0.000 & -0.001 & 0.046 & 0.038 & 0.210 & 0.102 & 0.885 \\
\hline
\end{tabular}




\section{Appendix C}

Table A3. Non-standard Total Effects.

\begin{tabular}{ccccc}
\hline Independent Variables & Dependent Variables & Direct Effect & Indirect Effect & Total Effect \\
\hline \multirow{2}{*}{ Delivery } & Manufacturer & 0.048 & 0.000 & 0.048 \\
& Customer & 0.000 & 0.000 & 0.000 \\
& Product & 0.000 & 0.000 & 0.000 \\
Customer & Manufacturer & 0.000 & 0.068 & 0.068 \\
& Delivery & 1.422 & 0.000 & 1.422 \\
& Product & 0.000 & 0.000 & 0.000 \\
\multirow{2}{*}{ Product } & Manufacturer & 0.056 & 0.007 & 0.064 \\
& Delivery & 0.000 & 0.155 & 0.155 \\
& Customer & 0.109 & 0.000 & 0.109 \\
\hline
\end{tabular}

\section{References}

1. Cooper, M.C.; Ellram, L.M. Characteristics of supply chain management and the implications for purchasing and logistics strategy. Int. J. Logist. Manag. 1993, 4, 13-24. [CrossRef]

2. Zhou, H.; Benton, W.C. Supply chain practice and information sharing. J. Oper. Manag. 2007, 25, 1348-1365. [CrossRef]

3. Samaddar, S.; Nargundkar, S.; Daley, M. Inter-organizational information sharing: The role of supply network configuration and partner goal congruence. Eur. J. Oper. Res. 2006, 174, 744-765. [CrossRef]

4. Jungbae Roh, J.; Hong, P.; Park, Y. Organizational culture and supply chain strategy: A framework for effective information flows. J. Enterp. Inf. Manag. 2008, 21, 361-376. [CrossRef]

5. Vanpoucke, E.; Boyer, K.K.; Vereecke, A. Supply chain information flow strategies: An empirical taxonomy. Int. J. Oper. Prod. Manag. 2009, 29, 1213-1241. [CrossRef]

6. Baihaqi, I.; Sohal, A.S. The impact of information sharing in supply chains on organisational performance: An empirical study. Prod. Plan. Control 2013, 24, 743-758. [CrossRef]

7. Li, J.; Sikora, R.; Shaw, M.J.; Woo Tan, G. A strategic analysis of inter organizational information sharing. Decis. Support Syst. 2006, 42, 251-266. [CrossRef]

8. Hellström, D.; Saghir, M. Packaging and logistics interactions in retail supply chains. Packag. Technol. Sci. Int. J. 2007, 20, 197-216. [CrossRef]

9. Ebeling, C.W. Integrated Packaging Systems for Transportation and Distribution; CRC Press: Boca Raton, FL, USA, 2013; ISBN 1482242966.

10. García-Arca, J.; Prado-Prado, J.C. Logistics improvement through packaging rationalization: A practical experience. Packag. Technol. Sci. Int. J. 2006, 19, 303-308. [CrossRef]

11. Lee, J.-E.; Lee, K.-D. Integrated forward and reverse logistics model: A case study in distilling and sale company in Korea. Int. J. Innov. Comput. Inf. Control 2012, 8, 4483-4495.

12. Twede, D. The process of logistical packaging innovation. J. Bus. Logist. 1992, 13, 69.

13. Wu, H.; Dunn, S.C. Environmentally responsible logistics systems. Int. J. Phys. Distrib. Logist. Manag. 1995, 25, 20-38. [CrossRef]

14. Andel, T. Packaging Basics (I). Transp. Distrib. 1996, 37, 113-118.

15. Benton, W.C.; Maloni, M. The influence of power driven buyer/seller relationships on supply chain satisfaction. J. Oper. Manag. 2005, 23, 1-22. [CrossRef]

16. Premus, R.; Sanders, N.R. Information Sharing in Global Supply Chain Alliances. J. Asia Pac. Bus. 2008, 9, 174-192. [CrossRef]

17. Rai, A.; Patnayakuni, R.; Seth, N. Firm Performance Impacts of Digitally Enabled Supply Chain Integration Capabilities. MIS Q. 2006, 30, 225-246. [CrossRef]

18. Cao, M.; Vonderembse, M.A.; Zhang, Q.; Ragu-Nathan, T.S. Supply chain collaboration: Conceptualisation and instrument development. Int. J. Prod. Res. 2010, 48, 6613-6635. [CrossRef]

19. Wiengarten, F.; Humphreys, P.; Cao, G.; Fynes, B.; McKittrick, A. Collaborative supply chain practices and performance: Exploring the key role of information quality. Supply Chain Manag. Int. J. 2010, 15, 463-473. [CrossRef] 
20. Kembro, J.; Näslund, D. Information sharing in supply chains, myth or reality? A critical analysis of empirical literature. Int. J. Phys. Distrib. Logist. Manag. 2014, 44, 179-200. [CrossRef]

21. Kembro, J.; Selviaridis, K.; Näslund, D. Theoretical perspectives on information sharing in supply chains: A systematic literature review and conceptual framework. Supply Chain Manag. Int. J. 2014, 19, 609-625. [CrossRef]

22. Tan, G.W. The Impact of Demand Information Sharing on Supply Chain Network. Ph.D. Thesis, University of Illinois at Urbana-Champaign, Champaign, IL, USA, 1999.

23. Bowersox, D.J.; Closs, D.J.; Cooper, M.B. Supply Chain Logistics Management, 2nd ed.; McGraw-Hill Education: New York, NY, USA, 2007; ISBN 9780072947885.

24. Heikkilä, J. From supply to demand chain management: Efficiency and customer satisfaction. J. Oper. Manag. 2002, 20, 747-767. [CrossRef]

25. Li, Z.; Shan, S. Essential of Supply Chain Strategic Management of Packaging Enterprises. Packag. Eng. 2006, 27, 64-65.

26. Lau, J.S.K.; Huang, G.Q.; Mak, K.L. Impact of information sharing on inventory replenishment in divergent supply chains. Int. J. Prod. Res. 2004, 42, 919-941. [CrossRef]

27. Croson, R.; Donohue, K.; Katok, E.; Sterman, J. Supply chain management: A teaching experiment. In Experimental Business Research; Springer: Berlin, Germany, 2005; pp. 285-296.

28. Bhatnagar, R.; Viswanathan, S. Re-engineering global supply chains: Alliances between manufacturing firms and global logistics services providers. Int. J. Phys. Distrib. Logist. Manag. 2000, 30, 13-34. [CrossRef]

29. Simchi-Levi, D.; Kaminsky, P.; Simchi-Levi, E. Designing and Managing the Supply Chain: Concepts, Strategies, and Case Studies; McGraw-Hill Education: New York, NY, USA, 2003; ISBN 0072492562.

30. Monczka, R.M.; Morgan, J. Questions you need to ask about your supply chain. Purchasing 1998, 124, 42-45.

31. Wadhwa, S.; Saxena, A. Decision knowledge sharing: Flexible supply chains in KM context. Prod. Plan. Control 2007, 18, 436-452. [CrossRef]

32. Riggins, F.J.; Mukhopadhyay, T. Interdependent Benefits from Interorganizational Systems: Opportunities for Business Partner Reengineering. J. Manag. Inf. Syst. 1994, 11, 37-57. [CrossRef]

33. Vijayasarathy, L.R.; Robey, D. The effect of EDI on market channel relationships in retailing. Inf. Manag. 1997, 33, 73-86. [CrossRef]

34. Moberg, C.R.; Speh, T.W. Evaluating the relationship between questionable business practices and the strength of supply chain relationships. J. Bus. Logist. 2003, 24, 1-19. [CrossRef]

35. Sahin, F.; Robinson, E.P., Jr. Information sharing and coordination in make-to-order supply chains. J. Oper. Manag. 2005, 23, 579-598. [CrossRef]

36. Moberg, C.R.; Cutler, B.D.; Gross, A.; Speh, T.W. Identifying antecedents of information exchange within supply chains. Int. J. Phys. Distrib. Logist. Manag. 2002, 32, 755-770. [CrossRef]

37. Seidmann, A.; Sundararajan, A. Sharing Logistics Information Across Organizations: Technology, Competition and Contracting. In Information Technology and Industrial Competitiveness; Springer: Boston, MA, USA, 1998; pp. 107-136.

38. Lee, H.L.; So, K.C.; Tang, C.S. The Value of Information Sharing in a Two-Level Supply Chain. Manag. Sci. 2000, 46, 626-643. [CrossRef]

39. Al-Mudimigh, A.S.; Zairi, M.; Ahmed, A.M.M. Extending the concept of supply chain: The effective management of value chains. Int. J. Prod. Econ. 2004, 87, 309-320. [CrossRef]

40. Sohal, A.S.; Power, D.J.; Terziovski, M. Supply chain management in Australian manufacturing-Two case studies. Comput. Ind. Eng. 2002, 43, 97-109. [CrossRef]

41. Dobson, G.; Pinker, E.J. The value of sharing lead time information. IIE Trans. 2006, 38, 171-183. [CrossRef]

42. Kaipia, R.; Holmström, J.; Småros, J.; Rajala, R. Information sharing for sales and operations planning: Contextualized solutions and mechanisms. J. Oper. Manag. 2017, 52, 15-29. [CrossRef]

43. Huo, B.; Han, Z.; Prajogo, D. Antecedents and consequences of supply chain information integration: A resource-based view. Supply Chain Manag. Int. J. 2016, 21, 661-677. [CrossRef]

44. García-Arca, J.; Carlos Prado Prado, J. Packaging design model from a supply chain approach. Supply Chain Manag. Int. J. 2008, 13, 375-380. [CrossRef]

45. Hellström, D.; Nilsson, F. Logistics-driven packaging innovation: A case study at IKEA. Int. J. Retail Distrib. Manag. 2011, 39, 638-657. [CrossRef] 
46. Sohrabpour, V.; Hellström, D.; Jahre, M. Packaging in developing countries: Identifying supply chain needs. J. Humanit. Logist. Supply Chain Manag. 2012, 2, 183-205. [CrossRef]

47. Kye, D.; Lee, J.; Lee, K.-D. The perceived impact of packaging logistics on the efficiency of freight transportation (EOT). Int. J. Phys. Distrib. Logist. Manag. 2013, 43, 707-720. [CrossRef]

48. García-Arca, J.; Prado-Prado, J.C.; Gonzalez-Portela Garrido, A.T. "Packaging logistics": Promoting sustainable efficiency in supply chains. Int. J. Phys. Distrib. Logist. Manag. 2014, 44, 325-346. [CrossRef]

49. Pålsson, H.; Hellström, D. Packaging logistics in supply chain practice-Current state, trade-offs and improvement potential. Int. J. Logist. Res. Appl. 2016, 19, 351-368. [CrossRef]

50. Twede, D. Logistics issues in returnable packaging. In Packaging Logistics Review; Packaging Logistics Symposium, Part of the NOFOMA 12th Annual Conference for Nordic Researchers in Logistics, Aarhus, Denmark, 14 June 2000; Econopap Publications: Helsinki, Finland; pp. 35-55.

51. Lee, J.-E.; Chung, K.-Y.; Lee, K.-D.; Gen, M. A multi-objective hybrid genetic algorithm to minimize the total cost and delivery tardiness in a reverse logistics. Multimed. Tools Appl. 2015, 74, 9067-9085. [CrossRef]

52. Selviaridis, K.; Matopoulos, A.; Thomas Szamosi, L.; Psychogios, A. Reverse resource exchanges in service supply chains: The case of returnable transport packaging. Supply Chain Manag. Int. J. 2016, 21, 381-397. [CrossRef]

53. Olorunniwo, F.O.; Li, X. Information sharing and collaboration practices in reverse logistics. Supply Chain Manag. Int. J. 2010, 15, 454-462. [CrossRef]

54. Fawcett, S.E.; Wallin, C.; Allred, C.; Fawcett, A.M.; Magnan, G.M. Information technology as an enabler of supply chain collaboration: A dynamic-capabilities perspective. J. Supply Chain Manag. 2011, 47, 38-59. [CrossRef]

55. Kim, Y.; Lee, Y.; Chung, K.-Y.; Lee, K.-D. An investigation on the information systems research in supply chain management: An analysis of research topic and methodology. Multimed. Tools Appl. 2015, 74, 8849-8860. [CrossRef]

56. Mirkovski, K.; Lowry, P.B.; Feng, B. Factors that influence interorganizational use of information and communications technology in relationship-based supply chains: Evidence from the Macedonian and American wine industries. Supply Chain Manag. Int. J. 2016, 21, 334-351. [CrossRef]

57. Saghir, M. Packaging information needed for evaluation in the supply chain: The case of the Swedish grocery retail industry. Packag. Technol. Sci. 2002, 15, 37-46. [CrossRef]

58. Amran, M.S.; Ahmed, M.; Shaheen, S.M.; Morshed, S.N.; Khandakar, M.J.A.; Rahman, M.M.; Rahman, M.M.; Hossain, M.A. Short communication a study on the packaging information of essential drug products used at union and thana health complex level in bangladesh. Pak. J. Pharm. Sci 2007, 20, 327-332. [PubMed]

59. Kim, M.K.; Lopetcharat, K.; Drake, M.A. Influence of packaging information on consumer liking of chocolate milk. J. Dairy Sci. 2013, 96, 4843-4856. [CrossRef] [PubMed]

60. Miraballes, M.; Fiszman, S.; Gámbaro, A.; Varela, P. Consumer perceptions of satiating and meal replacement bars, built up from cues in packaging information, health claims and nutritional claims. Food Res. Int. 2014, 64, 456-464. [CrossRef] [PubMed]

61. Kersbergen, I.; Field, M. Alcohol consumers' attention to warning labels and brand information on alcohol packaging: Findings from cross-sectional and experimental studies. BMC Public Health 2017, 17, 123. [CrossRef] [PubMed]

62. Duffy, E.; Gibney, M.J. Use of a food-consumption database with packaging information to estimate exposure to food-packaging migrants: Expoxidized soybean oil and styrene monomer. Food Addit. Contam. 2007, 24, 216-225. [CrossRef] [PubMed]

63. Arslanagić, M.; Peštek, A.; Kadić-Maglajlić, S. Perceptions of healthy food packaging information: Do men and women perceive differently? Procedia Soc. Behav. Sci. 2014, 109, 78-82. [CrossRef]

64. Gámbaro, A.; Roascio, A.; Boinbaser, L.; Parente, E. Influence of packaging and product information on consumer perception of cosmetic creams-A case study. J. Sens. Stud. 2017, 32, e12260. [CrossRef]

65. Jönson, G. Corrugated Board Boxes and Plastic Crates Used in the Distribution of Food; Working Paper; Lund University Press: Lund, Sweden, 1997.

66. Mentzer, J.T.; DeWitt, W.; Keebler, J.S.; Min, S.; Nix, N.W.; Smith, C.D.; Zacharia, Z.G. Defining supply chain management. J. Bus. Logist. 2001, 22, 1-25. [CrossRef] 
67. Carrillo, E.; Varela, P.; Fiszman, S. Packaging information as a modulator of consumers' perception of enriched and reduced-calorie biscuits in tasting and non-tasting tests. Food Qual. Prefer. 2012, 25, 105-115. [CrossRef]

68. Kim, Y.; Choi, H.; Lee, K. The impact of RFID implementation on pharmaceutical supply chain management. Information 2012, 15, 6205-6226.

69. Ha, O.; Park, M.; Lee, K.; Park, D. RFID application in the food-beverage industry: Identifying decision making factors and evaluating SCM efficiency. KSCE J. Civ. Eng. 2013, 17, 1773-1781. [CrossRef]

70. Ha, O.-K.; Song, Y.-S.; Chung, K.-Y.; Lee, K.-D.; Park, D. Relation model describing the effects of introducing RFID in the supply chain: Evidence from the food and beverage industry in South Korea. Pers. Ubiquitous Comput. 2014, 18, 553-561. [CrossRef]

71. Hoelter, J.W. The analysis of covariance structures: Goodness-of-fit indices. Sociol. Methods Res. 1983, 11, 325-344. [CrossRef]

72. Byrne, B.M. Structural Equation Modeling with AMOS: Basic Concepts, Applications, and Programming; Psychology Press: London, UK, 2001.

73. West, S.G.; Finch, J.F.; Curran, P.J. Structural equation models with nonnormal variables: Problems and remedies. In Structural Equation Modeling: Concepts, Issues, and Applications; Sage Publications, Inc.: Thousand Oaks, CA, USA, 1995; pp. 56-75. ISBN 0-8039-5317-8.

74. Muthén, B.; Kaplan, D. A comparison of some methodologies for the factor analysis of non-normal Likert variables. Br. J. Math. Stat. Psychol. 1985, 38, 171-189. [CrossRef]

75. Gerbing, D.W.; Anderson, J.C. Monte Carlo evaluations of goodness-of-fit indices for structural equation models. Sage Focus Ed. 1993, 154, 40. [CrossRef]

76. Tanaka, J.S. How Big Is Big Enough? Sample Size and Goodness of Fit in Structural Equation Models with Latent Variables. Child Dev. 1987, 58, 134-146. [CrossRef]

77. Steiger, J.H. Structural Model Evaluation and Modification: An Interval Estimation Approach. Multivar. Behav. Res. 1990, 25, 173-180. [CrossRef] [PubMed]

78. Bentler, P.M. Comparative fit indexes in structural models. Psychol. Bull. 1990, 107, 238. [CrossRef] [PubMed]

79. Hoyle, R.H.; Panter, A.T. Writing about structural equation models in structural equation modeling. In Structural Equation Modeling: Concepts, Issues, and Applications; SAGE Publications: Thousand Oaks, CA, USA, 1995; pp. 158-176.

80. Hair, J.F.; Black, W.C.; Babin, B.J.; Anderson, R.E.; Tatham, R.L. Multivariate Data Analysis; Pearson Prentice Hall: Upper Saddle River, NJ, USA, 2006; Volume 6. 